\title{
THE INFLUENCE OF TUG READINESS AND MARINE PILOT FOR PILOTAGE SERVICES - CASE STUDY AT PORT OF TANJUNG PRIOK, 2016-2017
}

\author{
Dinda Oktafia ${ }^{1}$, Ajeng Gustina ${ }^{2}$, Sarovah Widiawati ${ }^{3}$ \\ 1. STMT Trisakti, 2. STMT Trisakti, 3. STMT Trisakti \\ $\triangle$ corresponding author: dindaoktafia28@gmail.com
}

\begin{abstract}
Pilotage and tugage are part of port services. They are needed in serving vessels berthing. The two factors affecting pilotage services are internal and external factors. The internal factors include the tug readiness and marine pilots while external factors include weather, channel and vessel traffic. The pilotage that does not meet good standard will face problems in the service. The problems that might occur include bad service quality and the difficulties to reach some targets. One of the targets of pilotage at a port is zero waiting time. The purpose of this research is to analyze the pilotage and tugage port services. The researchers found some of activities (with the subjective) in data. The data shows that the paired test waiting on $1^{\text {st }}$ semester 2016 and the $1^{\text {st }}$ semester 2017 is -0.28333 in average with 0.002 as the significant value. It means that there is a significant difference. It concludes that the port activities cannot be handled well without tug and marine pilot.
\end{abstract}

Keyword : Marine Pilot, Tug, Service, Port, Pilotage

\section{Introduction}

GT 500 size or bigger vessels sailing in the compulsory waters and extraordinary compulsory waters are obliged to use pilotage services (Indonesia Gov., 2008). Pilotage service is defined as an activity to guide vessels in entering or leaving of the port safely or change the position of the vessels by professional pilots (IMO, 2014). When entering a port, the foreign vessels must accept pilotage of harbor states. It is not only necessary for safety, but also a demonstration of sovereignty, and it is compulsory (Xu $\& \mathrm{Xu}, 2016)$.

Based on realization of pilotage, shipping companies often complain about the delay services of pilotage, which have an impact to waiting time (ocean week. news, 2017 ). Shipping line company agents face continuous heavy delays because of marine pilots and tug services. The problem always happens. Even after it has been communicated with the operator, it never has any progress. This happens because the marine pilot in the task still 
depends on the facilities and infrastructure tools of pilotage (Sari.et.al., 2016).

To ensure the tug ready for operations and meet safety requirements and seaworthiness, it can be seen from the high level of readiness, then maintenance should be performed regularly and properly (Susilo, 2010). It includes running repair (The repair is carried out at the time of the fleet is in use), daily maintenance, and docking repair (Najoan.et.al., 2016). If the maintenance is not carried out regularly, it will have impact toward the fleet's leak time. That also affects the trust of sea transport services users (Lesmini \& Purwanto, 2016). Otherwise, maintenance of the ship held reasonably and consistently will impact upon (1) The longevity of the ship. (2) Ensuring the reliability of operation. The physical condition of the ship's engines is good. With a good condition boats will be able to increase efficiency and productivity. (3) The high readiness of the ship will facilitate the management in formulating plans and achieving its targets (Susilo, 2010).

The public service is a service by government agencies that act as providers of services to the society. Services provided must have a standardized procedures to achieve the target (Mirnasari, 2013). Manegement service provider must prossess speed and reliability in responding service ussers. The company must be quality-oriented. The service provided should be in accordance with the targets set by the company (Thamrin.et.al., 2016).

Pilotage service is one of the users-satisfaction oriented businesses. Pilotage activities include planning of pilotage, the start of act of pilotage, and end of pilotage (Lappalainen.et.al, 2011). Key performance indicators for pilotage are based on local standard (internal). Ports in the world use zero waiting time for pilot service as one of the successful indicators of pilotage service(Sari.et.al., 2016). To ease the scientific research and study, the researchers submit a research model, but this model is used to facilitate in grouping for understanding the flow of the research, the mind map is below. 


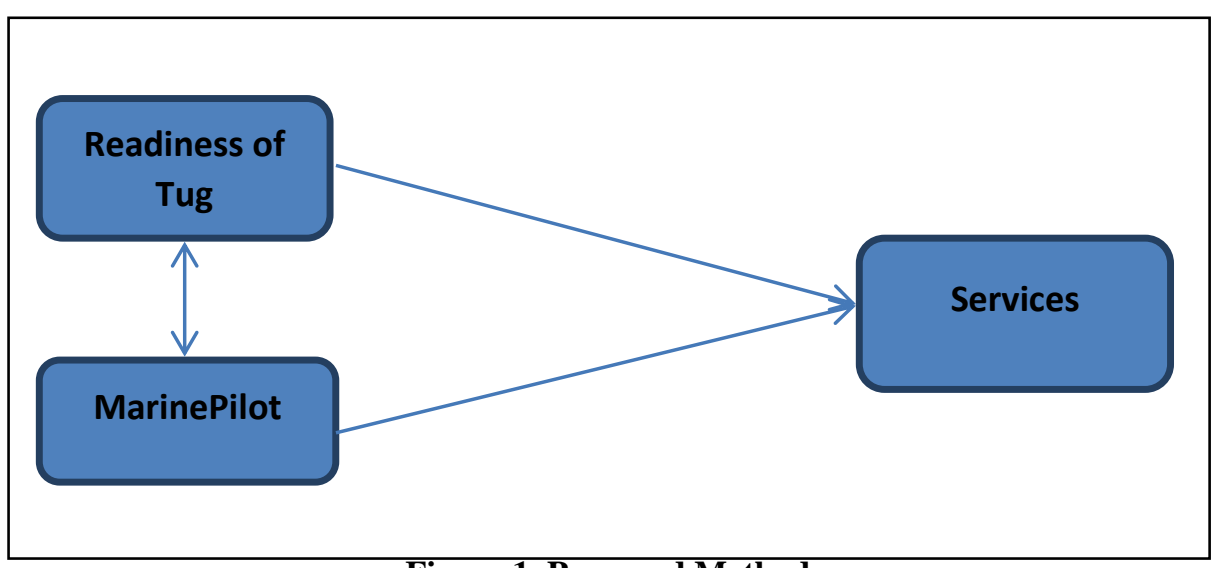

Figure 1. Proposed Method

\section{Method}

In this paper, the researcher described the study with descriptive explorative majoring on qualitative analysis with in-depth interview with tug operator and marine pilot.

\section{Result and Discussion}

As the main port in Indonesia, Tanjung Priok port has to ensure the key performance indicators, focusing on-time service to achieve zero waiting time and high level of services for the availability of readiness of the tug boats and pilotage (Susilo, 2010).

To ensure good service, pilot personnel, infrastructure, pilotage, and things correlated with improving pilotage service should be enhanced (Sari.et.al, 2016).

Tugage Case: For exploring of the tugage case, the data is below

1. About the total of tug owned by IPC

Table 1. List of Tug $2016 \& 2017$

\begin{tabular}{|c|c|}
\hline Year & Amount of Tug \\
\hline 2016 & 18 \\
\hline 2017 & 21 \\
\hline
\end{tabular}

Source : PT. Jasa Armada Indonesia, 2017

In the first semester of 2016, the company had 18 tugs. In onesemester (6 months: January - June 2016) number of tug movement was 
20,418 with 12,501 total ship call, so the average movement in the first semester was 1.63 .

Whereas in the first semester of the year 2017, the company rented three units, so it became 21 units. In one semester (6 months: January June 2017) the number of tug movement was 21,690 with 13,658 total ship call, so the average movement in the first semester was 1.58. The data shows that in 2017 the tugs owned were 21 units and 3 of them were rented. The additional ships was rented to improve the service of pilotage which has been hampered due to the lack of operating fleet tug.

To describe the readiness of tugs to the vessels in pilotage services, the table is below.

The Readiness of Tug to the Serviced Vessels 2016

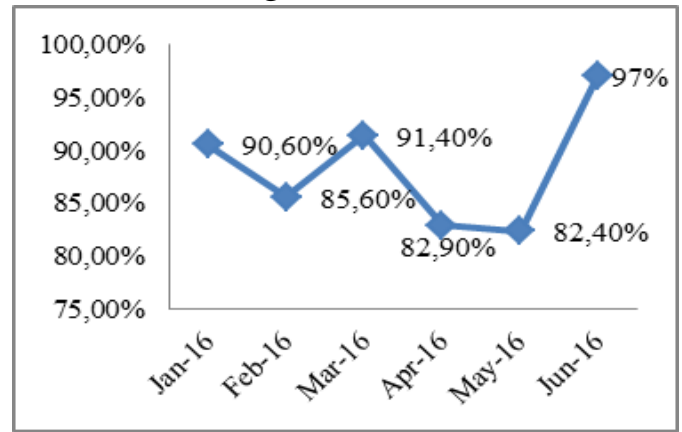

Figure 2. Tug Readiness 2016

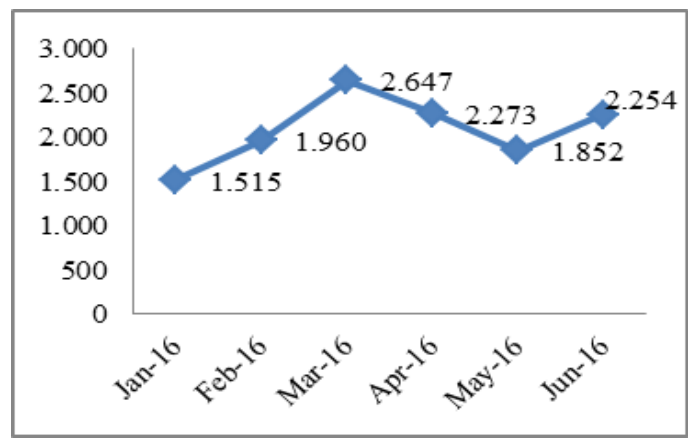

Figure 3.Ship Call 2016

Based on the chart, the average readiness of the tugs in a semester (JanuaryJune) in 2016 was $89.8 \%$ with 12,501 ship call. 
The Readiness of Tug to the Serviced Vessels 2017

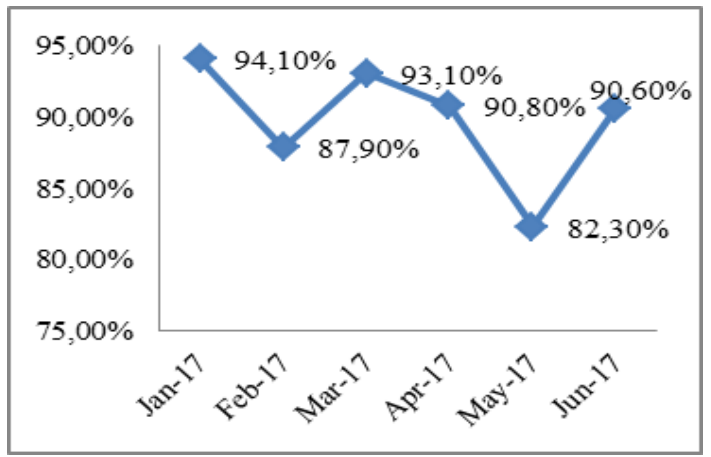

Figure 4. Tug Readiness 2017

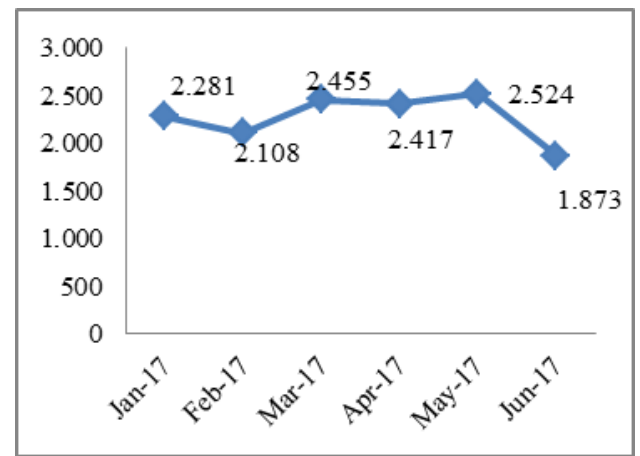

Figure 5. Ship Call 2017

The graph shows the average readiness of the tugs in one semester (January - June) in 2017 was $74.7 \%$. The readiness of the tugs did not affect the number of ship visits. It is visible from the percentage of readiness of the tug in 1st semester in 2016 was higher than 1st semester of 2017, but ship calls were lower than the $1^{\text {st }}$ semester of 2017 , which were 13,658 . The paired test is shown below

Table 2. Paired Test for Tug Readiness 2016 \& 2017

\begin{tabular}{|c|c|c|c|}
\hline Tug Readiness & N & Mean & Mean Difference \\
\hline Jan-Jun 2016 & 6 & 0,8833 & \multirow{2}{*}{$-0,01500$} \\
\hline Jan-Jun 2017 & 6 & 0,8983 & \\
\hline
\end{tabular}

The result of the paired test shows that the average difference in the readiness of the tugs between the $1^{\text {st }}$ semester of 2016 with the $1^{\text {st }}$ semester of 2017 was -0.01500 . It means that there was a difference of -0.01500 (but) 
very insignificant. The paired test of tugs movement in $1^{\text {st }}$ semester 2016 and $1^{\text {st }}$ semester 2017 is below.

Table3. Paired Test for Tug Movement 2016 \& 2017

\begin{tabular}{|c|c|c|c|c|c|}
\hline $\begin{array}{c}\text { TUG } \\
\text { Movement }\end{array}$ & $\mathrm{N}$ & Mean & Mean Difference & $\mathrm{t}$ value & Sig \\
\hline Jan-16 & 18 & 164,0000 & \multirow{2}{*}{$-9,76190$} & \multirow{2}{*}{$-0,364$} & \multirow{2}{*}{0,720} \\
\hline Jan-17 & 18 & 173,7619 & & & \\
\hline Feb-16 & 18 & 158,9524 & \multirow{2}{*}{11,47619} & \multirow{2}{*}{0,401} & \multirow{2}{*}{0,693} \\
\hline Feb-17 & 21 & 147,4762 & & & \\
\hline Mar-16 & 18 & 170,4762 & \multirow{2}{*}{$-4,71429$} & \multirow{2}{*}{$-0,109$} & \multirow{2}{*}{0,914} \\
\hline Mar-17 & 21 & 175,1905 & & & \\
\hline Apr-16 & 18 & 163,7619 & \multirow{2}{*}{$-11,28571$} & \multirow{2}{*}{$-0,319$} & \multirow{2}{*}{0,753} \\
\hline Apr-17 & 21 & 175,0476 & & & \\
\hline May-16 & 18 & 170,3333 & \multirow{2}{*}{$-25,95238$} & \multirow{2}{*}{$-0,633$} & \multirow{2}{*}{0,534} \\
\hline May-17 & 21 & 196,2857 & & & \\
\hline Jun-16 & 18 & 144,7619 & \multirow{2}{*}{$-3,38095$} & \multirow{2}{*}{$-0,093$} & \multirow{2}{*}{0,927} \\
\hline Jun-17 & 21 & 148,1429 & & & \\
\hline
\end{tabular}

The result shows no significant difference from the number of movements of the tug in 2016 compared to the first semester activities in 2017. However, it has been found that the data comparison in May 2016 2017 may have differences with the most prominent data. It has the distinction of the highest (-25.95238) meaning there are differences of the movement to reach 25.9 points. This was because of the visits of the ship were quite high. However, overall it can be concluded that the activity of the delay of the ship in the 1st semester 2016 and 2017 tend to be static.

There are few things that cause the pilotage service less than optimal and also delays. This study found constraints such as:

1) The high demand of ships at the same time, especially at the weekend

2) Fleet maintenance conditions are beyond suspicion (engine trouble, daily maintenance, propeller hits unidentified objects, or docking ship)

3) Unreadiness of marine pilots due to on-the-spot reasons.

4) The weather factors, where the wind speed affects service. The bigger the ships are, the greater the risks they have. (NOTE: Conditions when the wind current is 40 knots, the Ministry will give a warning to better safety). If it is not possible to do, wait until the weather is supporting. 
Marine pilot case: The quality of a company depends very much on good human resources as well as the main leverage of the company assets, such as capital, machinery, production equipment (fleet) and so on. With the quality, companies will have more value to enhance the professionalism, and services that the company provides in accordance with the company targets (Lasse.et.al., 2016). Based on the result of the research (in-depth interview), all marine pilots agreed that the priority of marine pilots is health, so that maintaining health with standards that are specified in the company supporting the activities of pilotage becomes absolute. The Health Maintenance of pilot personel is carried out with examination to differentiated age of each personnel. The table is as follows:

Table 4. Periodic Medical Check Up

\begin{tabular}{|c|c|c|}
\hline Years old & Frequent of medical c/u & Remarks \\
\hline$<50$ & 1 & a year \\
\hline$>50$ & 2 & a year \\
\hline
\end{tabular}

Job rotation system, marine pilot must serve customers within 24 hours, then the necessary division of work hours. Of course this is not easy, so the company decided the division of labor with the shift model, and shift division is divided in 2 shifts, the following table specifies the working hours.

Table 5. Marine Pilot Shift

\begin{tabular}{|l|l|l|}
\hline Shift & Hrs & Remarks \\
\hline I & $08: 00-18: 00$ & Shift 1 \\
\hline II & $18: 01-07: 59$ & Shift 2 \\
\hline
\end{tabular}

The number of pilot in port of Tanjung Priok 2017 until the semester 1 has been 36 people, which are divided into 4 groups. To maintain the stamina of pilots as well as the service, it is required to split the off duty schedule, and the division is as follows: 1 day morning shift, 1 day night shift, 2 days off.

Although it had been arranged in such a way, in the implementation some of the pilot personnel had constraints so they were absent on duty. This became one of the causes of no maximum service due to"waiting time"and "On Duty" pilots got fatigue because of extra work. The lack of 
personnel caused problems, for example because retired pilots and there has not been a replacement and there was a pilot who was sick and could not work, etc.

Pilotage by pilot personnel at the port starts with planning of pilotage personnel before the pilotage. They have to learn about the ship they will serve. The important thing is pilotage personnel have to know about the draught of the ship. The pilot personnel also have to communicate with the berth parties and the pilotage tower about the condition of the path. If the condition is good they are allowed to enter the vessel and see the helm to ask about the readiness of the ship including machine, crew members, gravity moment, ship's document and cargo. When everything is ready, the pilot does the pilotage. The pilot also needs to communicate with the agent for asking the ship's position and the anchor, with the berth in a dispute to check the condition of the berth readiness, and with mooring for berthing vessel. If pilotage activity is done on auto pilot (pilotage activities in general are more or less the same), pilotage activity is under control by the pilot and the captain just monitors the activity. At the end of pilotage activity, the pilot gives instruction to the captain related to the safety of the shipping and provides verification about the weather of the state that may happen. (Lappailanen.et.al., 2011). Pilotage is effective if the service of pilotage is on time. The measurement of the successful pilotage activities at Tanjung Priok port is if there is no constraint of pilotage berthing safely.

The pilotage activities had some constraints such as misscommunication with the tugs often complained by the pilots for example: the instruction of moving the tug to the west and to the north or east) or the tug is late so the process of berthing and unberthing vessel was delayed. As a result the service is not effective. Another problem by pilot personnel was the condition of the Indonesian vessels which had less safety such as engine trouble, the vessel was forced to berthing or sailing which might cause an accident (collision or crash) at harbor area. This was because the inspection of vessels was not done carefully due to the demand of the vessels inspection was not proportional to the number of marine inspectors 
(Saribanon \& Sakti, 2016). In addition, traffic flow of the harbor was tight for outgoing and incoming vessels because the channel in the water was only one, so the vessel had to stand in line to be served.

The different perception between marine pilots in this study, researchers got some differences perception between marine pilots for example:

a) Some pilots felt tired if they worked at night shift but some pilots felt tired if working in bad weather that caused the waiting time.

b) Some pilots pointed great tug with HP (Horse power) to carry out pilotage with the safety purpose and some other pilots receive only a tug that helped the ability of the horse power of tug crews and affected the approaching time.

c) Some pilots were convenient guiding vessels with LOA $<200 \mathrm{M}$, but some other was convenient guided the vessel with LOA > $200 \mathrm{M}$. T vessel with LOA > $200 \mathrm{M}$ that used computerized technology was more stable in pilotage activity (Technology affect service).

d) Some pilots got complain from captains because of tugs and rope unpreparedness related delays (equipment affected the safety while working) and others pilot got complain about the vessels that did not want to use tug because the vessels had bow thrusters (use tug in accordance with the addition of the cost to high-tech ship). To complete these services about waiting time service was presented below.

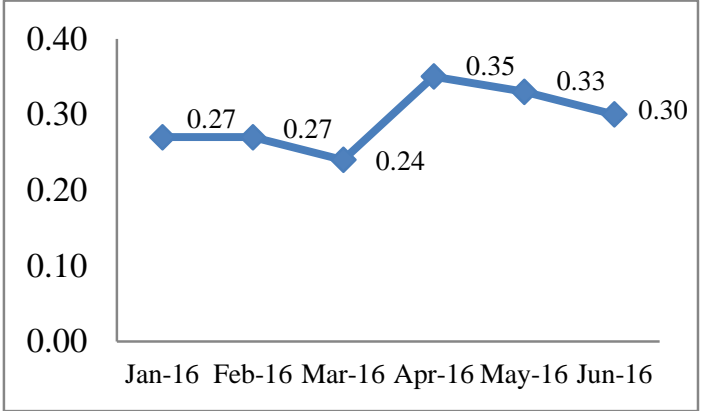

Figure6. Waiting Time 2016

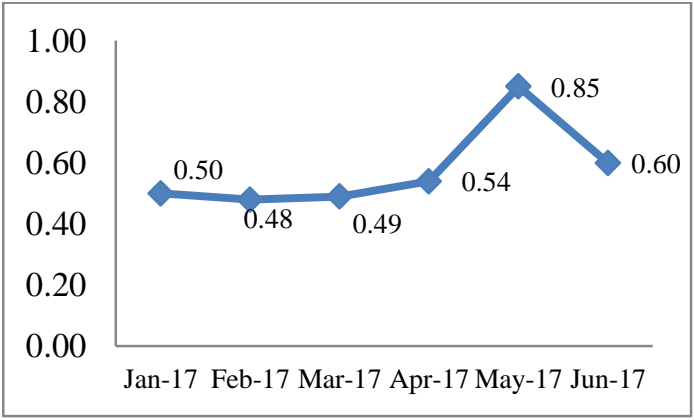

Figure 7. Waiting Time 2017

The graph shows that the waiting time in $1^{\text {st }}$ semester 2017 was higher than the $1^{\text {st }}$ semester 2016. It means that the service in 2017 was down. Some 
division managers of pilotage must improve the service. The below as paired test for waiting time.

Table6. Paired Test for Waiting Time 2016 \& 2017

\begin{tabular}{|c|c|c|c|c|c|}
\hline Waiting Time & $\mathrm{N}$ & Mean & Mean Difference & t value & Sig \\
\hline Jan-Jun 2016 & 6 & 0,2933 & \multirow{2}{*}{$-0,28333$} & $-5,692$ & 0,002 \\
\hline Jan-Jun 2017 & 6 & 0,5767 & & \\
\hline
\end{tabular}

The results indicates that there is difference in average of waiting time in $1^{\text {st }}$ semester 2016 and $1^{\text {st }}$ semester 2017 . The difference is -0.28333 with significant 0.002 value which means that there is difference but it is not significant for waiting time in $1^{\text {st }}$ semester 2016 and $1^{\text {st }}$ semester 2017.

\section{Conclusion}

Fleet replenishment efforts did not provide increased service. It could be seen from the significance of the number of tugboat movement in the service of pilotage vessels that tend to be static. Percentage of availability of the tugboats was quite good and had improvement in 2017. However there were several fleets that could not be operated optimally due to the routine maintenance and daily maintenance or another reason to assist the services in different branch. The company did not only increased the tug fleet but required the addition of pilot personnel. If the tugs are ready but the pilot personnel are not, pilotage service cannot be implemented and it has impact to "waiting time problem" and it becomes the complain of the customer.

The quantity of tug has affected the service levels. Miscommunication caused bad services, even contributing cause of the accident. Different opinion in pilotage activity also hampered the services, so it requires the standardization on all lines.

Effective service on berthing and unberthing the vessel is the result of collaboration between the tug, marine pilots, and administration. Pilotage without good collaboration will not satisfy customers. Good coordination delivers good service. The service will be synchronous if the tugs and marine pilots collaborate properly. 


\section{References}

IMO. (2014). Maritime (Pilotage) Regulations 2014.

Indonesia Gov. (2008) U.-U. N. 17 T. 2008.

Lasse, D. et. al. (2016). Pelatihan Keselamatan Bagi Anak Buah Kapal, 257-266.

Lesmini, L., \&Purwanto, B. (2016). Ekonomi Maritim \& Sumber Daya Manusia Indonesia, 372-389.

Lappalainen. et.al. (2011). Effectiveness of pilotage.

Mirnasari, R. M. (2013). Inovasi Pelayanan Publik UPTD Terminal Purabaya-Bungurasih, 1, 71-84.

Najoan, D. et. al. (2016) Hubungan Biaya Material Kapal Terhadap Laba Operasi, 276-286.

Saribanon, E. et. al. (2016)Kinerja Pelayanan Pemeriksaan Kapal, 85-94.

Sari, I. C. et. al. (2016). Peran Approaching Time Dalam Peningkatan Pelayanan Jasa Pemanduan Kapal Di Pelabuhan Utama Tanjung Priok The Role Of Approaching Time On Pilotage Services at The Port Of Tanjung Priok, 7(2), 191-199.

Susilo, H. (2010). Improving Vessel Service Performance by Optimizing Pilot and Tug Services: the case of The Port of Tanjung Priok, Indonesia by Herman Susilo.

Thamrin, M. et. al. (2016) Kualitas Pelayanan Jasa Keagenan Kapal Dan Komunikasi Interpersonal Pada Services Quality Of Ship Agency Services And Interpersonal Communication In Shipping Companies, $3(2), 217-225$.

Xu, P., \& Xu, L. (2016). On the Establishment of Particularly Sensitive Sea Area ( PSSA ) in the Strait for the Prevention of Vessel-sourced Pollution, (Iceep), 148-154.

http://oceanweek.co.id/2017/08/29/pandu-tunda-sebaiknya-dikelola-satupaket/(retrieved on October 20, 2017) 